\title{
THE IMPACT OF TOURIST ACCOMMODATION DEVELOPMENT TOWARD THE SOCIO-CULTURAL ASPECTS IN THE SEMINYAK VILLAGE, DISTRICT OF KUTA, REGENCY OF BADUNG, BALI (IN PERSPECTIVE OF THE LOCAL COMMUNITY)
}

\author{
Kadek Wiweka SST.Par, M.Par, M.Rech \\ Tourism Department, \\ Sahid Tourism institute (STP SAHID) \\ Jalan Kemiri \\ wiweka.kadek88@gmail.com
}

\author{
Komang Trisna Pratiwi Arcana SST.Par, M.Par, M.Rech \\ Tourism Management Program, \\ The International Bali Tourism Institute (STPBI), \\ Jalan Tari Kecak No.12 Gatot Subroto Timur, \\ Denpasar - Bali, Indonesia 80239 \\ trisnapratiwi.arcana@gmail.com
}

\begin{abstract}
The growth of tourism accommodation (villa) in the district of Kuta Utara, which is so rapid and uncontrolled, tends to have raised some concerns on the impact that may arise (socio-cultural, environmental and economic). The gap between benefit and cost of the phenomenon raises the question of how perception, response, changes the behavior of the culture and mindset of the local community towards the development of their area travel accommodation. To examine the case, this study combines the two forms of both quantitative and qualitative methodologies (multi-method). The qualitative methods done by observing a research site to see the behavior of local people in the village of Seminyak and informal talks (interview) that is guided by an interview guidelines related to the perception of the local community, the village headman, and the managers of accommodation (villa). While quantitative methods conducted by distributing questionnaires to local communities $(90$ respondents) were selected randomly. The result of this study is the public response to the development of the accommodation is in the phase of "Euphoria". It is seen from some of the symptoms, which generally public responses tend to more focus on the advantage of the economic aspects and as if the exclusion of other effects that arise as the socio-cultural and environmental.
\end{abstract}

Keywords: Perception; Local Communities; Tourist Accommodation; Seminyak

\section{Introduction}

Without any doubt, in recent decades, tourism has grown into a sector that is relied upon to stimulate the economy in the national and international scope. UNWTO (2016) noted that in 2015, the growth of international tourists reached 1,184 million tourists, or grew by $4.4 \%$ from the previous year, when the biggest growth occurred in the Asia and Pacific region by $4-5 \%$. While Bali as one of the mainstay tourist destinations in Indonesia recorded a growth of tourist arrivals in 2015 by $6.42 \%$ or 4 million travelers compared to 2014 (3.7 million). The phenomenon of growth in tourist arrivals to Bali will certainly encourage an increased need or demand of tourists; one of them is from the accommodation sector. The Central Bureau of Statistics Bali (2016) noted that in 2013 occurred a growing number of accommodations (Star Hotel) by $4.1 \%$ to as much as 227 hotels from the year 2012 amounted to 218 hotels. With the growing trend of travelers which are likely to continue to rise, is feared more uncontrolled growth of accommodation. This concern is based on the data distribution of accommodation growth, which amounted to $64.3 \%$ in the area of Badung and the rest spread successively $13.7 \%$ in Denpasar, $8 \%$ in Gianyar, 6\% in Buleleng, $3 \%$ in Karangasem and Klungkung and by $0.8 \%$ in Jembrana and Tabanan.

Unequal growth in tourism to a destination would make some impacts, either negative impact (cost) and benefit from tourism activities against most regions, in this case the Badung regency. One impact of the development of tourism accommodation in Badung is conversion or land use, where productive land (agricultural) used as tourist accommodation (Evita et al., 2012: 11). That 
phenomenon will ultimately affect the local traditions, which the Balinese culture that is built on the values of an agrarian culture will gradually change through geographical conditions.

Changes in culture behavior and mindset of the local community to the development of tourism, especially in the aspect of tourist accommodation in Badung then become an interesting issue to be studied. This research has focused on knowing how the perception of the local community in Seminyak village, Kuta, Badung toward the development of tourism accommodation. The study was inspired by several studies (Doxey, 1975; Monterrubio and Bello, 2011) who believed that the perception of local communities will continue to change as the intensity of the interaction between tourism activities and local community. Those changes can be affected by how far the benefits and negative impact (cost) accrued by the local community. Hence, this study is no longer discusses the impact of all tourism activities, but more focused on how the perception of local communities to the tourism development itself.

\section{Literature Review \\ 2.1. The Impact of Tourism}

Tourism is an industry that involves various dimensions. This phenomenon happened because during the process, tourists who travel to a destination will bring their customs and culture, as well as interact with local communities, including elements of the sociocultural, environmental, and economic. These interactions could potentially influence each element, not only for local community but also for the tourists themselves. That influence can be classified into two categories, such as positive (benefits) and negative (costs). That issue also has been studied by many researchers, as follow:

a. Socio- cultural aspects; tourism as a means of preserving the art and culture (Howe 2006:135; Setyagung et al., 2013: 27; Ismalasari and Suparwoto, 2014: 210), tourism as a form of commoditization and commercialization of arts, culture and religion (Shepherd, 2002:193; Greenwood, 1977: 130; Cohen, 1988: 371-383; Cole, 2008: 144-147; Lisette, 2013: 79-80;
Kontogeorgopoulos et al., 2015), tourism is a form of acculturation (Smith, 2003: 53; Holden, 2005: 157; Berry, 2005: 700), tourism led to the marginalization of local communities (Azhar, 2013; Pandit, 2012: 44-48), tourism causes the demonstration effect on local communities (Yasothornsrikul and Bowen, 2015: 99 ), tourism led to the development of drugs, alcohol, and prostitution (Smith, 2003: 50; Monterrubio and Bello, 2011: 17-18), tourism causes congestion (Wiersma and Robertson, 2003: 157).

b. While the environmental aspect, few researches have examined several focuses include: tourism can cause physical environment and ecology degradation (United Nations Research Institute for Social Development, 1994), tourism causes environmental pollution (Scott, 2008; Tapper et al., 2011: 15), tourism led to an increase in land use (Howe 2006: 145; Jeff and Belinda, 2009: 66; Pringle, 2004: 191; Windia, 2015), tourism is also increasing over the ownership of land (Sveinsdóttir, 2014: 106), tourism causes changes in the behavior of the native fauna (Saputra et al., 2014: 14-15; Pelletier, 2006: 17), tourism contributes to climate change (Scott, 2008). Generally from these two aspects, both socio-cultural and environmental, tourism is often seen as the "unfriendly" industry.

c. But, it is different in economy aspect, several studies have tended to see tourism as industries that bring benefits, such as: tourism can encourage infrastructure development, increase income and purchasing power, creating new jobs, until the multiplier effect, such as the role of the export and import.

In the context of this study, some of the benefits and impacts of the above is believed to affect the perception of the local community to the development of tourism in a destination. Many references about the tourism influence are used as materials to look for information about perceptions of local community in Seminyak village. 


\section{2. "Residents' Perception}

One of the studies that have been done related to the local perception is the research conducted in Tafi Athome, Ghana titled "Residents' Perception of Socio-economic Impacts of Tourism" (Mensah, 2012). This paper stated that the local perception of the tourism development in that area tend to be positive, especially from the perspective of its impact on social and economic elements. Specifically, local communities view that tourism contributed to the preservation of the apes in Mona and saw that native faunas are not disturbed by tourism activity. Besides, local people also benefit an economic advantage by opening occupations, although not many investors are interested to invest in their environment. When viewed through the concept of Doxey's Irridex, the local communities are still in a phase of "euphoria" or are enjoying the benefits of tourism activities characterized by openness of local people towards tourists and investors as well as the lack of planning in developing tourism.

\section{Methodology}

This study used the theory of irritation index (Irridex) Doxey as the primary measurement tool in discussing about the perception or the public response to the development of the tourism sector, which more specifically examines the interactions and relationships between tourists and local communities. This study illustrated that local public opinion towards tourism activity can continue to grow along with the benefits or impact (either directly or indirectly) that they receive. The issue is relevant to the actual conditions that are developing in the village of Seminyak, district of Kuta, Bali, where the village has grown so rapidly, especially in the tourism accommodation sector. It certainly has the potential to give rise to diverse local perceptions that are influenced by tourism activity in the area.

To examine this phenomenon, the research methodology combines quantitative and qualitative methodology or commonly known as a "multi- method" (Jonker and Pennink, 2010: 92). Qualitative methods are done by non- participant observation to study sites to see the behavior of local people in the village of Seminyak. Further data collection in this period performed by interview (Sugiyono, 200) or informal talk guided by instrument or guidelines interviews related to the response of the local community, the village headman, and the managers of accommodation (villa) by using purposive sampling toward the benefits and impact of the development of tourism accommodation.

While distributing a questionnaire or data collection techniques by providing a set of did the quantitative method questions (with a measurement scale rating scale) to the local community (90 respondents) were selected randomly (simple random sampling) associated with the response to the development of the sector of tourist accommodation. The data collection were analyzed using descriptive statistical techniques or by describing the data that has been collected and presented through a table (Sugiyono, 2007).

\section{Result}

\subsection{Profile of Community and Indigenous Village of Seminyak}

Seminyak Indigenous Village is located in village of Seminyak, district of Kuta, Badung regency. Village of Seminyak consists of two hamlets namely Banjar Basangkasa which citizens belong to the Village of Kerobokan and Banjar Seminyak which citizens belong to Seminyak Village. Both of these village is the site of this study and distributed in several areas including Umalas area Kauh and Kangin, Umasari region, Desa Canggu and the village of Kerobokan. Badung regency was chosen to be the location of this research because in recent years, the development of tourism accommodation especially villa, developed so rapidly in the area of Kuta. The largest percentage is in the area of Kuta Utara (45.6\%), which has an area of $33.86 \mathrm{~km}^{2}$, district of Kuta amounted to $18.31 \%, 17.78 \%$ for South Kuta, $17.61 \%$ for Mengwi, and of $0.70 \%$ are Abiansemal. The spreading of the construction of villas was $57.41 \%$ in the rural areas and the rest are in coastal areas (Evita et al., 2012). Based on this background, this research focused on North Kuta area which recorded a very significant if the villa growth compared to other regions. 
Based on data from BPS (2016), Dependency Ratio of communities in North Kuta is stable, where a row from 2013 to 2015 stood at 42.730, 42.550 and 42.330 inhabitants. While the population density of the years 2013 to 2015 has increased the numbers recorded at $3427.35 \quad$ inhabitants $/ \mathrm{km}^{2}, \quad 3.538,39$ inhabitants $/ \mathrm{km}^{2}$ and in 2015 reached 3651.21 people $/ \mathrm{km}^{2}$. This figure is the second highest of the seven other areas after Kuta. North Kuta is also a sub-district with the highest population growth rate $(6.97 \%)$ from 2000 2010, after South Kuta which reached 9.13\%. Based on these data, it can be seen in general district of North Kuta began experiencing rapid growth, where it is also in tandem with the growth of travel activity, particularly in terms of the development of tourist accommodation (villa).

\subsection{Residents' Responds of Tourism Impacts (Accommodation-Villa)}

The results of this study were the responses from 90 local communities. The respondents were chosen randomly, but are limited by the geographical location of Seminyak village.
The public response is grouped into three parts, which include local community's response to the development of accommodation related to socio-cultural aspects, environmental aspects and economic aspects. The results of these studies are presented in tabular form and will be described in terms of the sentences.

\section{a. Residents' Responds of Socio-Culture Impact of Tourism}

The first question is a group of questions related to socio-cultural aspects. The respondents were questioned about whether the development of tourism (tourism accommodation) gives effect to 13 variables related to socio-cultural aspects. Where there is further provided possible answers ranging from very insignificant, insignificant, do not know, significant and very significant.

Table 1.Residents' Responds of Socio-Culture Impact of Tourism

\begin{tabular}{|c|c|c|c|c|c|c|c|c|c|c|c|}
\hline \multirow[t]{2}{*}{ No } & \multirow[t]{2}{*}{ List of Questions } & \multicolumn{2}{|c|}{$\begin{array}{c}\text { Very } \\
\text { insignificant }\end{array}$} & \multicolumn{2}{|c|}{ Insignificant } & \multicolumn{2}{|c|}{$\begin{array}{l}\text { Do not } \\
\text { know }\end{array}$} & \multicolumn{2}{|c|}{ Significant } & \multicolumn{2}{|c|}{$\begin{array}{c}\text { Very } \\
\text { Significant }\end{array}$} \\
\hline & & $\sum$ & $\%$ & $\sum$ & $\%$ & $\sum$ & $\%$ & $\sum$ & $\%$ & $\sum$ & $\%$ \\
\hline 1. & $\begin{array}{l}\text { The preservation of art and } \\
\text { culture in your village? }\end{array}$ & 12 & 13.33 & 3 & 3.33 & 6 & 6.67 & 33 & 36.67 & 36 & 40.00 \\
\hline 2. & $\begin{array}{l}\text { Community behavior in } \\
\text { your village? }\end{array}$ & 12 & 13.33 & 9 & 10.00 & 9 & 10.00 & 33 & 36.67 & 27 & 30.00 \\
\hline 3. & $\begin{array}{l}\text { The moral of people in your } \\
\text { village? }\end{array}$ & 6 & 6.67 & 12 & 13.33 & 21 & 23.33 & 36 & 40.00 & 15 & 16.67 \\
\hline 4. & Individual criminal cases? & 30 & 33.33 & 18 & 20.00 & 15 & 16.67 & 24 & 26.67 & 3 & 3.33 \\
\hline 5. & Group criminal cases ? & 42 & 46.67 & 24 & 26.67 & 12 & 13.33 & 12 & 13.33 & 0 & - \\
\hline 6. & $\begin{array}{l}\text { The presence of illegal } \\
\text { drugs in society? }\end{array}$ & 27 & 30.00 & 12 & 13.33 & 30 & 33.33 & 18 & 20.00 & 3 & 3.33 \\
\hline 7. & $\begin{array}{l}\text { The existence of alcoholic } \\
\text { beverages in public? }\end{array}$ & 24 & 26.67 & 3 & 3.33 & 6 & 6.67 & 33 & 36.67 & 24 & 26.67 \\
\hline 8. & $\begin{array}{l}\text { The changes in ways of } \\
\text { thinking? }\end{array}$ & 18 & 20.00 & 3 & 3.33 & 3 & 3.33 & 39 & 43.33 & 27 & 30.00 \\
\hline 9. & $\begin{array}{ll}\text { The existence } & \text { of } \\
\text { prostitution in society? }\end{array}$ & 24 & 26.67 & 27 & 30.00 & 21 & 23.33 & 9 & 10.00 & 9 & 10.00 \\
\hline 10. & $\begin{array}{l}\text { The presence of free sex } \\
\text { behavior? }\end{array}$ & 24 & 26.67 & 30 & 33.33 & 24 & 26.67 & 3 & 3.33 & 9 & 10.00 \\
\hline 11. & $\begin{array}{l}\text { The traffic congestion in } \\
\text { your area? }\end{array}$ & 6 & 6.67 & 33 & 36.67 & 0 & - & 24 & 26.67 & 27 & 30.00 \\
\hline 12. & $\begin{array}{l}\text { Noise pollution in your } \\
\text { village? }\end{array}$ & 18 & 20.00 & 24 & 26.67 & 3 & 3.33 & 24 & 26.67 & 21 & 23.33 \\
\hline 13. & religious ceremony? & 24 & 26.67 & 9 & 10.00 & 0 & - & 15 & 16.67 & 42 & 46.67 \\
\hline
\end{tabular}


The list of questions is also equipped with a column or part of information that can be used by respondents to describe more specific reasons. Such information is also very helpful in describing the response from the respondents.

Based on the survey conducted to 90 respondents, it can be seen the response of local communities to influence the development of accommodation to sociocultural factors as indicated in the table above. The response of the local community of which amounted to $76.67 \%$ of respondents believe that the development of a positive influence accommodation ( $40 \%$ is very significant and $36.67 \%$ is significant) toward the preservation of art and culture in their area. While the response of the community related with the behavior of people in Seminyak village, around $66.67 \%$ of respondents thought positively where $36.67 \%$ said significant and $30 \%$ said very significant. Positive responses were also given relating to the effect on public morals, in which $40 \%$ of respondents believe significant and very significant around $16.67 \%$.

While the influence of tourism on the increase in individual criminal cases, amounting to $33.33 \%$ of respondents think it is very insignificant and $20 \%$ is insignificant. Similarly influence on their group criminal cases as many as $46.67 \%$ of respondents think it is very insignificant and $26.67 \%$ is insignificant. While the influence of the presence of illegal drugs amounted to $33.33 \%$ of respondents did not know and 30\% thought it was very insignificant. However, the public response about the existence of alcoholic beverages in public, around $36.67 \%$ said significant and $26.67 \%$ said very significant.

The development of tourism is also considered to significantly affect the change in the society's ways of thinking $(43.33 \%$ is significant, $30 \%$ is very significant). This is contrast when related to the existence of prostitution in society, where the majority of respondents found was not significant $(26.67 \%$ is very significant, $30 \%$ is insignificant). Similar responses were also seen in the variable presence of free sex behavior, where $26.67 \%$ of respondents think it is very insignificant and $33.33 \%$ is insignificant. The development of accommodation towards the level of traffic congestion in the area is also considered to be insignificant by $36.67 \%$ of respondents, but $56.67 \%$ of respondents said it is significant $(26.67 \%$ significantly and $30 \%$ very significantly). The interesting one is the effect on noise (noise pollution), which is around $26.67 \%$ is insignificant, but $26.67 \%$ of respondents said it is significant. As the role of tourism to cultural factors, religious ceremony is also thought to be influenced significantly by $16.67 \%$ and $46.67 \%$ of respondents stated very significant.

\section{b. Residents' Responds of Environmental Impact of Tourism}

The second question is a group of questions related to environmental aspects. Where respondents were questioned about whether the development of tourism (tourism accommodation) gives effect to the 7 variables related to environmental aspects. As in the socio-cultural group of questions is also equipped with a column or part of information that can be used by the respondent to explain the specific reasons related to the response of the respondents on the environmental aspects.

In general, the development of tourism accommodation is considered potential effects on the environment in Seminyak village. Based on data from this study, as many as $83.33 \%$ of respondents argued that the land use is influenced significantly ( $40 \%$ said significant, $43.33 \%$ said very significant) by the development of tourism accommodation. While $80 \%$ of respondents ( $30 \%$ is significant, $50 \%$ is very significant) argues that these developments also affect the phenomenon of over ownership of land from the local communities to investors. More than $70 \%$ of respondents (30\% is significant and $43.33 \%$ is very significant) stated that the significant physical changes in term of structure and portion in Seminyak village environment caused by the development of tourism accommodation. But in terms of environmental preservation, although more than $50 \%$ of the respondents $(46.67 \%$ said significant and around $13.33 \%$ is very significant) stated significantly influenced by the development of tourism accommodation, on the other hand as many as $30 \%$ of respondents said insignificant. Similarly, the preservation of the native fauna in the village of Seminyak, $60 \%$ of 
respondents $(20 \%$ said very insignificant and $40 \%$ said insignificant) said the developments do not affect nor has no significant effects. Another case with environmental pollution especially for rivers and rice fields, more than $60 \%$ of the respondents $(36.67 \%$ said significant, $30 \%$ said very significant) stated significant. As the phenomenon of accommodation development in other areas, in the village of Seminyak, the availability of water in a village environment is also affected significantly $(40 \%$ of respondents stated significant and $33.33 \%$ stated very significant).
Based on the data in the table 3, in general the development of tourism accommodation is considered as a positive influence in the economic aspect in the village of Seminyak. It is certainly not so surprising because generally the development of tourism in the various sectors likely to benefit from the economic aspect. However, this study tries to evaluate the response of local communities related to both economic benefits that they receive.

Table 2.Residents' Responds of environmental impact of tourism

\begin{tabular}{|c|c|c|c|c|c|c|c|c|c|c|c|}
\hline \multirow[t]{2}{*}{ No } & \multirow[t]{2}{*}{ List of questions } & \multicolumn{2}{|c|}{$\begin{array}{c}\text { Very } \\
\text { insignificant }\end{array}$} & \multicolumn{2}{|c|}{ Insignificant } & \multicolumn{2}{|c|}{$\begin{array}{l}\text { Do not } \\
\text { know }\end{array}$} & \multicolumn{2}{|c|}{ Significant } & \multicolumn{2}{|c|}{$\begin{array}{c}\text { Very } \\
\text { Significant }\end{array}$} \\
\hline & & $\sum$ & $\%$ & $\sum$ & $\%$ & $\sum$ & $\%$ & $\sum$ & $\%$ & $\sum$ & $\%$ \\
\hline 1. & $\begin{array}{l}\text { Land use/conversion in } \\
\text { your village? }\end{array}$ & 12 & 13.33 & 3 & 3.33 & 0 & - & 36 & 40.00 & 39 & 43.33 \\
\hline 2. & $\begin{array}{l}\text { Over ownership of land } \\
\text { from local communities to } \\
\text { the investor? }\end{array}$ & 12 & 13.33 & 3 & 3.33 & 3 & 3.33 & 27 & 30.00 & 45 & 50.00 \\
\hline 3. & $\begin{array}{l}\text { Physical changes (structure, } \\
\text { portions) of environment in } \\
\text { your village? }\end{array}$ & 12 & 13.33 & 3 & 3.33 & 9 & 10.00 & 27 & 30.00 & 39 & 43.33 \\
\hline 4. & $\begin{array}{llr}\begin{array}{l}\text { Preservation } \\
\text { environment }\end{array} & \text { of } & \text { the } \\
\text { village? } & \text { your }\end{array}$ & 3 & 3.33 & 27 & 30.00 & 6 & 6.67 & 42 & 46.67 & 12 & 13.33 \\
\hline 5. & $\begin{array}{l}\text { Preservation of the native } \\
\text { fauna in your village? }\end{array}$ & 36 & 40.00 & 18 & 20.00 & 21 & 23.33 & 12 & 13.33 & 3 & 3.33 \\
\hline 6. & $\begin{array}{l}\text { Pollution of } \\
\text { environment (rivers, rice } \\
\text { fields) in your village? }\end{array}$ & 18 & 20.00 & 3 & 3.33 & 9 & 10.00 & 33 & 36.67 & 27 & 30.00 \\
\hline 7. & $\begin{array}{l}\text { The availability of water in } \\
\text { the neighborhood of your } \\
\text { village? }\end{array}$ & 9 & 10.00 & 15 & 16.67 & 0 & - & 36 & 40.00 & 30 & 33.33 \\
\hline
\end{tabular}

\section{c. Residents' Responds of economic impact of tourism}

Furthermore, on the third question, a group of questions related to the economic aspects. Where respondents were questioned about whether the development of tourism (tourism accommodation) gives effect to 10 variables related to economic aspects. As in the previous section, the group this question is also equipped with a column or part of information that can be used by the respondent to explain the specific reasons related to the respondent's response to economic aspects.
This study found that more than $80 \%$ of the respondents (33.33\% said significant and $53.33 \%$ said very significantly) believes that the development of tourism accommodation significantly effect on the creation of new jobs in Seminyak village. Although at the same time, more than $70 \% \quad(33.33 \%$ stated significant and $43.33 \%$ stated very significant) of the respondents argued that it also causes changes in the livelihoods of local communities.

While as many as $50 \%$ of respondents $(40 \%$ is significant and $10 \%$ is very significant) believes that the development of learning 
infrastructure (schools) is significantly affected. Similarly to the development of health infrastructure such as hospitals (33.33\% said significant, $16.67 \%$ said very significantly and $23.33 \%$ said insignificant) and for construction of road access infrastructure in the village (36.67\% is significant and $33.33 \%$ is very significant). But the development of tourism accommodation is considered no effect $(20 \%$ is insignificant, $33.33 \%$ is very insignificant) significantly to the development of sports infrastructure and public entertainment. Furthermore, over $70 \%$ of respondents (36.67\% is significant and $36.67 \%$ is very significant) argues increasing people's income is significantly affected, where it is also affected significantly $(43.33 \%$ is significant and $30 \%$ is very significant) on improving people's purchasing power.
A total of $73.33 \%$ of the respondents $(23.33 \%$ is significant and $50 \%$ is very significant) holds that the quality of their lives also positively influenced significantly by the development of tourism accommodation. Similarly, for the development of infrastructure of cleanliness in the village of Seminyak, around $43.33 \%$ said significant and $26.67 \%$ said very significant.

\section{Discussion}

Based on the data above, this study found that local community in the village of Seminyak still give a positive response to the development of tourism in their area, especially in terms of the development of tourism accommodation (villa).

Table 3.Residents' Responds of Economic Impact of Tourism

\begin{tabular}{|c|c|c|c|c|c|c|c|c|c|c|c|}
\hline \multirow[t]{2}{*}{ No } & \multirow[t]{2}{*}{ List of Question } & \multicolumn{2}{|c|}{$\begin{array}{c}\text { Very } \\
\text { insignificant }\end{array}$} & \multicolumn{2}{|c|}{ Insignificant } & \multicolumn{2}{|c|}{$\begin{array}{l}\text { Do not } \\
\text { know }\end{array}$} & \multicolumn{2}{|c|}{ Significant } & \multicolumn{2}{|c|}{$\begin{array}{c}\text { Very } \\
\text { Significant }\end{array}$} \\
\hline & & $\sum$ & $\%$ & $\sum$ & $\%$ & $\sum$ & $\%$ & $\sum$ & $\%$ & $\sum$ & $\%$ \\
\hline 1. & $\begin{array}{l}\text { The creation of new jobs in } \\
\text { the neighborhood of your } \\
\text { village? }\end{array}$ & 9 & 10.00 & 0 & - & 3 & 3.33 & 30 & 33.33 & 48 & 53.33 \\
\hline 2. & $\begin{array}{l}\text { Development of learning } \\
\text { infrastructure (schools) in } \\
\text { your village? }\end{array}$ & 18 & 20.00 & 9 & 10.00 & 18 & 20.00 & 36 & 40.00 & 9 & 10.00 \\
\hline 3. & $\begin{array}{l}\text { Development of health } \\
\text { infrastructure (hospitals) in } \\
\text { your village? }\end{array}$ & 21 & 23.33 & 12 & 13.33 & 12 & 13.33 & 30 & 33.33 & 15 & 16.67 \\
\hline 4. & $\begin{array}{l}\text { Construction of the road } \\
\text { access infrastructure in your } \\
\text { village? }\end{array}$ & 12 & 13.33 & 9 & 10.00 & 6 & 6.67 & 33 & 36.67 & 30 & 33.33 \\
\hline 5. & $\begin{array}{l}\text { Development of } \\
\text { infrastructure of sport and } \\
\text { public entertainment? }\end{array}$ & 30 & 33.33 & 18 & 20.00 & 12 & 13.33 & 15 & 16.67 & 15 & 16.67 \\
\hline 6. & $\begin{array}{l}\text { Improving people's } \\
\text { purchasing power? }\end{array}$ & 6 & 6.67 & 12 & 13.33 & 6 & 6.67 & 39 & 43.33 & 27 & 30.00 \\
\hline 7. & $\begin{array}{l}\text { Increasing people's } \\
\text { incomes? }\end{array}$ & 9 & 10.00 & 12 & 13.33 & 3 & 3.33 & 33 & 36.67 & 33 & 36.67 \\
\hline 8. & $\begin{array}{l}\text { Improving the quality of the } \\
\text { community's life? }\end{array}$ & 15 & 16.67 & 6 & 6.67 & 3 & 3.33 & 21 & 23.33 & 45 & 50.00 \\
\hline 9. & $\begin{array}{l}\text { Changes in local people's } \\
\text { livelihood? }\end{array}$ & 9 & 10.00 & 3 & 3.33 & 9 & 10.00 & 30 & 33.33 & 39 & 43.33 \\
\hline 10. & $\begin{array}{l}\text { Development of } \\
\text { infrastructure of cleanliness } \\
\text { in your village? }\end{array}$ & 12 & 13,33 & 9 & 10 & 6 & 5,67 & 39 & 43,33 & 24 & 26,67 \\
\hline
\end{tabular}


This can be seen from the local community's response to the phenomenon in several aspects; socio-cultural, environmental, and economic. In the socio-cultural aspect, people tend to think positively to influence the development of tourism accommodation in their area. It can be seen how the perception of local community toward the development of tourism accommodation give significant effect on the preservation of art and culture, as well as the activities of religious ceremonies. Tourism activities are also considered not significantly affect the existence or development of drugs, prostitution and free sex, as well as criminal cases, both individuals and groups. But the development of tourism accommodation in Seminyak village has a significant effect on moral behavior and local communities, as well as the existence of alcoholic beverages. It is part of the impact of demonstration effect, which is accepted by the community due to the interaction with tourists. As for the other variables are considered by local communities that give significantly negative effect is the emergence of congestion and noise pollution, although the majority (over $40 \%$ of respondents) local people felt the opposite (insignificant).

While the environmental aspect, in general, local people tend to argue that the development of tourist accommodation in their village brings a significant negative impact. Some negative impacts are felt by local communities, such as conversion and land ownership, which is also in line with the opinion of the interview with the head of Banjar Umasari, Mr. Suardika (2015). He argue that, "In this region, there were a lot of over the land ownership, which has affected the livelihoods of local communities who formerly as a farmer, but now prefer to sell their land to be used as tourist accommodation" . In addition, several other impacts include physical changes in term of structure and portions, environmental pollution especially on rice fields and rivers, as well as affecting the availability of clean water. However, the development of tourism accommodation also contributes to the awareness on environmental preservation in Seminyak village.

In contrast to the opinion of the local community to influence the development of tourism accommodation on the environmental aspects, that tend to be negative. In response to the economic aspects of local communities tend to reverse (positive). This is certainly not so surprising. It is considered that the positive effect is generally perceived by the public in a quick period of time is the economic sector. Around $90 \%$ of economic variables declared positive and significant influence, which are the creation of new jobs that affect the increase in income and purchasing power, so it comes down to improving the quality of life. Besides the development of tourism accommodation also has some effects on the construction of roads access, learning infrastructure (school), hospitals, and sanitation infrastructure. But people argue that the development of infrastructure of sports and public entertainment has not been significantly affected. The phenomenon that become a concern is the change in the livelihood of local communities, particularly if previously farmer livelihoods. As time being, this will certainly affect the sustainability of agriculture in the village of Seminyak.

Based on these findings, it can be seen that the response of the local community on the development of tourist accommodation in the village of Seminyak still tend to be positive, or in other words, they accepted the existence of tourist activity. Specifically, according to Doxey theory, the tendency of public responses toward the development of accommodation is on the phase of "Euphoria". It can be seen from the indicators that appear, such as local community still support tourism development and have been used to live side by side with tourists in daily life. In general, local people are still likely to feel the benefit or profit from tourism activities such as the existence of new employment opportunities, increased incomes and purchasing power, which also contributed to the increasing quality of life for local communities. Beside the individual benefit, the local communities also get the profits of tourism accommodation developments that affect the construction of road access, learning infrastructure (schools), hospitals, and sanitation infrastructure. Based on the theory, this stage occurs when the economy of local communities was stagnating and the tourism sector is seen as a solution or alternative to get out of the situation. The public responses also tend to be more focused on the benefits of the economic aspects and as 
if the exclusion of other affects that arise as the socio-cultural and environmental.

\section{References}

Anonim, "UNWTO 2016". Tourism Highlights 2016 Edition. Volume 14, Advance Release January 2016.

Anonim, "Banyaknya Hotel Berbintang di Bali Menurut Lokasi dan Kelas Hotel Tahun 2013". Badan Pusat Statistik.

http://bali.bps.go.id/tabel detail.php?ed=611003\&od $=11$ \&id=11, 2016.

Anonim, "Kedatangan Wisatawan Mancanegara yang Langsung ke Bali Berdasarkan Negara Pasar Utama: Th.2012, Th.2013, Th.2014, Th.2015, 2016", 2016. http://www.disparda.baliprov.go.id/id/Statistik2.

Azhar, Muhamad Ali, "Marginalisasi Masyarakat Di Daerah Pariwisata (Studi Kasus di Desa Ungasan Kecamatan Kuta Selatan Kabupaten Badung)".Jurnal Ilmiah Administrasi Publik dan Pembangunan, Vol. 4, No.2, Juli-Desember 2013.

Berry, John W, "Acculturation: Living successfully in two cultures. International Journal of Intercultural Relations, 29, 2005, 697-712, pp. 699.

Buhalis, D, "Marketing the Competitive Destination of Future". Tourism Management 21, 97-116 dalam http://www.elsevier.com/locate/tourman, 2000, diakses 14 Februari 2013.

Cohen, Erik, "Authenticity and Commoditization in Tourism". Annal of Tourism Research, Vol. 13, pp. 371386,1988 .

Cole, Stroma, "Tourism, Culture and Development, Hopes, Dreams and Realities in East Indonesia".Tourism And Cultural Change 12. Series Editors: Mike Robinson and Alison Phipps. British Library Cataloguing in Publication Data. CHANNEL VIEW PUBLICATIONS, 2008, pp. 19-20, 23.

Cooper, Chris et al. (1996). "TOURISM Principles \& Practice".Addison Wesley Longman Limited, Edinburg Gate, Harlow, Essex, CM20 2JE, England. Pg. 80, 81, $94-96,100$

Cordero, Juan. (2008). "Residents Perception of Tourism: A Critical Theoretical and Methodological Review". CIENCI Aergosum, Vol. 1 5- 1, marzo- junio 2008. Universidad Autó nomadel Estadode México, Toluca, México. Pp. 35-44.

Evita et al. (2012). "Dampak Perkembangan Pembangunan Sarana Akomodasi Wisata Terhadap Pariwisata Berkelanjutan di Bali". Jurnal Ilmiah Pariwisata, ISSN: 1858-070x, Volume 2 No.1, pp. 109222 September 2012.
Greenwood, Davydd J., (1977). "Culture by the pound: an Anthropological Perspective on Tourism as Cultural Commoditization." From Smith, Valene L., Host and Guest: the Anthropology of Tourism. Pp. 129-138, 301 H67: Blackwell Publisher. Pg. 130-136.

Holden, Andrew, "Tourism Studies and the Social Sciences". Routledge, 2 Park Square, Milton Park, Abingdon, Oxon OX14 4RN, 2005, pp. 39, 156-159.

Howe, Leo, "The Changing World of Bali. Religion, Society and Tourism."Routledge 270 Madison Ave, New York, NY 10016, 2006, pp. 144, 145.

Ismalasari, Meita Rini dan Suparwoto. (2014). "Perkembangan Kesenian Paguyuban Wayang Orang Bharata Di Jakarta Tahun 1972-2012". Avatara, e-Journal Pendidikan Sejarah.Volume 2, No. 1, March 2014. pp. 210.

Jeff Lewis and Belinda Lewis, "Bali's Silent Crisis, Desire, Tragedy, and Transition.A division of Rowman \& Littlefield Publishers, Inc". A wholly owned subsidiary of The Rowman \& Littlefield Publishing Group, Inc. 4501 Forbes Boulevard, Suite 200. Lanham, MD 20706. United Kingdom, 2009, pp. 67

Kontogeorgopoulos, Nick et al, "Homestay Tourism and the Commercialization of the Rural Home in Thailand".Asia Pacific Journal of Tourism Research. Vol. 20, No. 1, pp. 2950,http://dx.doi.org/10.1080/10941665.2013.852119. 2015.

Lisette, Van Der Burg, "Commoditization Of The Ju/'Hoansi Culture: Destroying Authenticity Or Revitalizing Tradition?, A Study on the Impacts of Cultural Tourism on the Ju/'hoansi San in the Nyae Nyae Conservancy, Namibia". Thesis of University of Leiden. Pg. 79-80, 2013.

Mensah, Christopher. (2012). "Residents' Perception of Socio-economic Impacts of Tourism in Tafi-Atome, Ghana". Asian Social Science; Vol. 8, No. 15; ISSN 1911-2017 E-ISSN 1911-2025. Published by Canadian Center of Science and Education, pp. 274-287, 2012.

Monterrubio, Juan Carlos dan Bello, Anallely, "Local community attitude towards the impact of tourism on prostitution". Jurnal of Tourism No. 12: 13-20. pp. 17-18, 2011.

Pandit, Suman, "Marginalization of the Tharu Ethnic Group in Tourism Development in Nepal". TURIZAM, Volume 16, Issue 2, pp. 40-49, pp. 44, 2012.

Pelletier, F. (2006). "Effects Of Tourist Activities On Ungulate Behaviour In A Mountain Protected Area". Département de biologie, Université de Sherbrooke, 2500 boulevard de 1'Université, Sherbrooke, Qc, J1K 2R1 Canada fanie.pelletier@Usherbrooke.ca. J. Mt. Ecol., 8: 2006: 15-19. Pg. 17. 
Pringle, Robert. (2004). "A Short History Of Bali, Indonesia's Hindu Realm”. Allen \& Unwin. Pg. 191, 195.

Saputra, Komang Gede Wahyu et al., "Aktivitas Harian Kera Ekor Panjang (Macaca Fascicularis) Di Taman Wisata Alam Sangeh, Kabupaten Badung, Bali”. Jurnal Biologi Volume 18 No.1 JUNI, 2014. pp. 14-15.

Scott, Daniel, "'Climate Change and Tourism: Responding to Global Challenges. CTO/ CRSTDP Regional Workshop The Bahamas, pp. 18-19 March, 2008 .

Setyagung, Estav $\mathrm{H}$ et al., "Preserving Cultural Heritage: The Harmony between Art Idealism, Commercialization, and Triple-Helix Collaboration." American Journal of Tourism Management 2013, 2(1): 22-28. pp. 27.

Shepherd, Robert, "Commodification, Culture and Tourism". Sage publications London, Thousand Oaks and New Delhi, Tourism Studies. Vol 2(2) 183-201. pp. 195, 2002.

Smith, Melanie K, "Issues in Cultural Tourism Studies." Routledge is an imprint of the Taylor and Francis Group, This edition published in the Taylor \& Francis e-Library, 2003. pp. 50-53.
Sveinsdóttir, Anna Guðbjört, "Land Tenure and Tourism Development in Nicaragua.A case study from Playa Gigante".Thesis for the Degree of Master of Philosophy in Culture, Environment and Sustainability. Centre for Development and the Environment University of Oslo Blindern, Norway. pp. 106, 2014

Tapper et al., "The impact of the tourism industry on freshwater resources in countries in the Caribbean, Mediterranean, North Africa and other regions".Research project for the Travel Foundation. Tourism \& Freshwater Resources: Report to the Travel Foundation. pp. 15, 2011.

Wiersma, Joshua dan Robertson, Robert, "Traffic Congestion And Tourism Displacement In The Nh Route $1 \mathrm{a} / 1 \mathrm{~b}$ Corridor: Does Sampling Method Matter?".Proceedings of the 2003 Northeastern Recreation Research Symposium. pp. 157, 2003.

Yasothornsrikul, Paradee dan Bowen, David, "Tourism Demonstration and Value Change". International Journal of Tourism Research, Int. J. Tourism Res., 17: 96-104, 2015, Pg. 99. 